\title{
Effect of Yaw Motion on the Propulsive Performance of Robotic Fish with Tail Fin Actuators
}

\author{
学 福㠃 昇 (阪市大院) 学 宇佐美 雄大 (阪市大院) \\ 正高田 洋吾 (阪市大院)
}

Noboru FUKUZAKI, Osaka City University, 3-3-138, Sugimoto, Sumiyoshi-ku, Osaka

Takahiro USAMI, Osaka City University

Yogo TAKADA, Osaka City University

1 緒言

水中生物に多くみられる尾ひれによる推進は, プロペラ 推進に比べ, 最高速度, 加速性能, 旋回性能などの面にお いて優れているとされている. しかし, 現在の尾ひれ推進 による魚ロボットの推進速度や推進効率は, 実際の生きた 魚に比べ未だに十分ではなく，生態系調査用などに実用化 を試みる場合は，現状よりも数倍高速化する必要がある. 過去の研究より, 魚ロボットは一関節で駆動する場合と比 ベて二関節で駆動する方が，推進性能が向上することが判 っている(1).

しかし，二関節駆動型の魚ロボットは遊泳中に体幹部に 回転中心を持つヨー運動を行い, 体全体を左右に摇動する. また，実際に体全体を摇動している魚の種類は多い，著者 らが過去に行った研究では，頭部を固定し，体幹部と尾ひ れのみを摇動する計算格子を用いて解析を行っていた， そ のため, ヨー運動が魚ロボットの推進性能に及ぼす影響に ついて検討することが出来ず，また，魚の遊泳を忠実には 再現出来ていないという問題があった.

そこで本研究では，頭部を固定せず，体全体を左右に摇 動することが出来るように，計算格子に改良を加えた。こ の改良によって，ヨ一運動が推進性能に与える影響につい て三次元流体構造連成計算で検討することを可能にした. 推進性能を向上させるためには魚ロボットがヨー運動を抑 えるように設計すべきか否かについて検討した.

\section{2 流体・構造連成計算手法}

本研究では, 流体・構造連成解析において, 流体の支配 方程式と構造の支配方程式を別々に解き, 流体構造境界面 において構造に対しては力学的境界, 流体に対しては幾何 学的境界を与える弱連成法を採用した. 流体解析(CFD)に は著者らの開発してきた 3 次元流動数値解析コード(2) (GTT コード)を用いた. 本 GTT コードは境界適合格子を適用し て流動解析を有限体積法に基づいて行い，今回は，ソルバ 一として SIMPLER 法を用いた. 尾ひれの弾性変形解析に は20 節点 6 面体 Serendipity 要素を用いた有限要素法 ${ }^{(3)} に よ$ り定式化を行った.

\section{3 ヨー運動が推進性能に与える影響}

3.1 使用した計算格子

本研究で使用した計算格子は $62 \times 50 \times 159$ に分割し, 魚 ロボット周りおよび尾ひれ後方は細かく分割している. ヨ 一運動を再現するために，まず，体幹部に中心のある摇動 を魚ロボット全体に対して行わせ，その状態で各関節を摇 動させた. 今回, 体幹部の摇動角を $\pm 10^{\circ}$, 尾ひれの摇動 角を $\pm 20^{\circ}$ とし, ヨー運動を行わない場合と行う場合で推 進力等の比較を行った。尾ひれ摇動角に対する体幹部摇動 角の位相差は $120^{\circ}$ としている.

推進性能の評価方法として, 式(1)に示す流体から受ける 力は流れに向かって進む力(正味推進力) $\overline{F_{p}}$ と, 流れに対 して垂直な力(横力) $\overline{F_{s}}$ の比(推進特性) $R_{a}$ を用いた. 正味 推進力は, 尾ひれを左右に摇動した結果, 前に進もうとす る力, 横力は, 尾ひれを左右に摇動するのに必要な力であ る.

$$
R_{a}=\frac{\overline{F_{p}}}{\overline{\left|F_{s}\right|}}
$$

\section{2 ヨー運動の有無による推進性能の比較}

体幹部と尾ひれを摇動させるとともに体全体も摇動し， ヨー運動を考慮した場合(Case A), 及び，頭部を固定した 状態で体幹部と尾ひれのみを摇動させた場合(Case B)の渦 度分布を図 1 に示す。

生きた魚が尾ひれを左右に摇動して遊泳する際，尾ひれ 後方に広がりの小さい渦列が発生する，渦列の広がり方は ヨ一運動をしない場合に比べて，する場合の方が小さい. このことからヨー運動をしている場合の方が生きた魚の遊 泳に近いことが判る。

次に, 正味推進力, 横力, 推進特性の值を図 2 に示す. ヨ一運動を行う場合と行わない場合を比較すると，行う場 合の方が, 正味推進力は小さく, 横力は大きくなるという 結果になり，推進特性が低下するという結果になった。こ れはヨー運動を行うことで流れに対する全面投影面積が大 きくなってことが原因であると考えることができる.

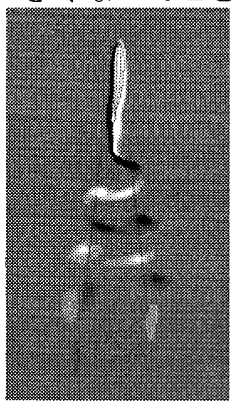

(a)With Yaw Motion

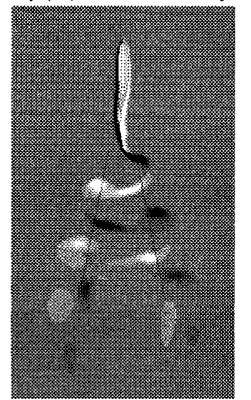

(b)Without Yaw Motion
Fig.1 Result of Computer Simulation

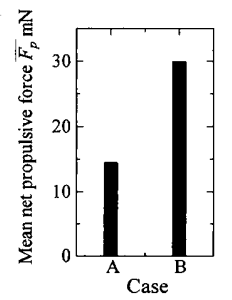

(a) Net propulsive force

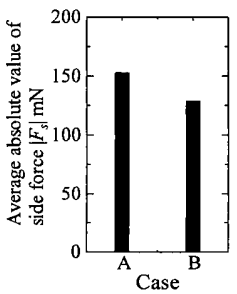

(b) Side force

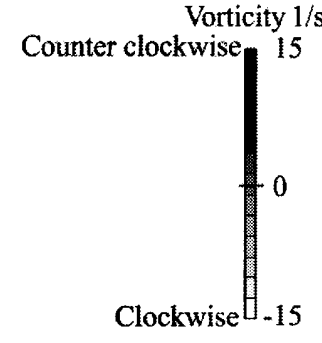

Fig.2 Evaluation results

4 結 言

遊泳中に行うヨー運動を考慮し，体全体を摇動させ，頭 部の摇動も行った場合, 推進力は低下し, 尾ひれを摇動す るのに必要な力は増加している。これらの影響によって推 進性能は低下してしまう。以上のことから，魚口ボットを 設計する際は, ヨ一運動を行わないように, 摇動角や, 重 心位置，機構を決定する必要があると考えられる。

$$
\text { 謝 辞 }
$$

本研究の一部は, 科学研究費(基盤研究(C)24560301)の援 助を受けた.ここに記して謝意を表する.

\section{参考文献}

(1) Y.Takada, T.Ochiai, N.Fukuzaki, T.Tajiri and T.Wakisaka, Journal of Aero Aqua Bio-mechanisms ,3(1), (2013),pp.57-64.

(2) 高田洋吾, 荒木良介, 落合利紀, 田尻智紀, 脇坂知行, 機論 C, 77(778), (2011), PP.2351-2362.

(3) 下関正義, 藤沼平一 PC-9801 有限要素法プログラミングの実際[ II ],(1991), 日刊工業新聞. 